\title{
IMPLEMENTASI METODE FORWARD CHAINING UNTUK MENDIAGNOSIS ORGANISME PENGGANGGU TANAMAN (OPT) KOPI
}

\author{
Andy Victor Pakpahan \\ Program Studi Teknik Informatika \\ STMIK LPKIA \\ Email: abang@lpkia.ac.id \\ Doni \\ Program Studi Teknik Informatika \\ STMIK LPKIA \\ Email: doni@lpkia.ac.id
}

\begin{abstract}
ABSTRAK
Organisme pengganggu tanaman (OPT) adalah semua organisme yang dapat menyebabkan dan menimbulkan kerusakan fisik, gangguan fisiologi dan biokimia, atau kompetisi hara terhadap tanaman budidaya. Penanggulangan dan pengendalian terhadap OPT harus dilakukan secara cepat dan tepat agar tidak menimbulkan permasalahan lain yang bersifat ekologi, sosial maupun ekonomi. Salah satu tanaman budidaya yang sering diserang oleh OPT adalah tanaman kopi. Tanaman kopi merupakan salah satu komoditas unggulan dan strategis di Jawa Barat yang mempunyai peran cukup penting dalam perekonomian masyarakat Jawa Barat. Edukasi pengendalian OPT di Jawa Barat belum berjalan secara merata dikarenakan letak geografis antar perkebunan sangat jauh satu sama lain. Hal ini berdampak terhadap minimnya pemahaman para petani terhadap pengendalian OPT dan buruknya kualitas kopi yang dihasilkan oleh para petani. Penulis bermaksud akan membuatkan aplikasi sistem pakar berbasis web untuk menjembatani dan mengakomodasi bentuk edukasi yang dapat dilakukan kapan saja dan dimana saja tidak terbatas oleh letak geografis. Melalui aplikasi ini petani dapat mendiagnosis, mendapatkan informasi gejala serta cara pengendalian OPT Kopi yang terjadi. Untuk melakukan diagnosis, penulis menggunakan teknik Forward Chaining dalam melakukan penelusuran kemungkinan gejala-gejala yang ada sampai dengan menemukan rekomendasi OPT yang berkesesuaian dengan hasil penelusuran gejala yang ditelusuri. Hasil penelitian menunjukkan $87 \%$ dari total keseluruhan responden setuju bahwa aplikasi yang dibangun dapat digunakan sebagai media konsultasi sekaligus memudahkan petani dalam menentukan cara pengendalian yang tepat terhadap serangan OPT Kopi yang terjadi tanpa harus berkonsultasi lebih lanjut dengan pihak atau dinas terkait.
\end{abstract}

Kata kunci: organisme pengganggu tanaman; forward chaining; aplikasi; kopi.

\begin{abstract}
Plant pest are all organisms that can cause physical damage, physiological and biochemical disorders, or nutrient competition among cultivated plants. Mitigation and control of pests must be carried out quickly and precisely so as not to cause other ecological, social or economic problems. One of the crops that is often attacked by plant pest is coffee. Coffee plants are one of the leading and strategic commodities in West Java that have an important role in the economy of the West Java community. Pest control education in West Java has not gone well because the differences between plantations are very significant. This has an impact on the lack of understanding of farmers on the control and quality of coffee they produced. The author will create an expert web-based system application to bridge and accommodate forms of education that can be done anytime and anywhere not limited by geographical places. This application can help diagnose, get information on symptoms and ways to control the pest. To make a diagnosis, the author uses the Forward Chaining technique in searching for existing facts to find a continuous pest with the search results of the symptoms traced. The results of the study show $87 \%$ of total respondents agree that the applications made can be used as media and also makse it easier for users to determine the right way to control the pests.
\end{abstract}

Keywords: plant pest organisms; forward chaining; application; coffee. 


\section{PENDAHULUAN}

Tanaman kopi merupakan salah satu komoditas unggulan dan strategis di Jawa Barat yang mempunyai peran cukup penting dalam perekonomian masyarakat Jawa Barat. Java Preanger Coffee atau yang sering disebut kopi priangan menjadi salah satu bukti bahwa kopi di Jawa Barat dapat menembus pasar dunia. Pada peringatan hari kopi internasional 1 oktober 2016, pemerintah Provinsi Jawa Barat melalui dinas perkebunan Provinsi Jawa Barat berencana membuat road map pengembangan java preanger coffee sebagai salah satu bentuk upaya pemerintah untuk menjadikannya sebagai ikon Jawa Barat serta senantiasa menjaga kualitas produksi dan nilai tambah peningkatan kesejahteraan para petani kopi [1]

Pada pelaksanaanya,budi daya serta produksi kopi di Jawa Barat menemui banyak kendala diantaranya adalah rendahnya produktivitas dan kualitas kopi yang dihasilkan. Tentu saja hal in berdampak terhadap perekonomian para petani dimana kualitas kopi yang buruk akan menurunkan harga jual kopi dipasaran. Rendahnya produktivitas dan kualitas kopi antara lain disebabkan oleh banyaknya serangan organisme pengganggu tanaman (OPT) seperti penggerek buah kopi, penggerek batang, karat daun, kutu hijau dan kutu putih [2]. Merujuk kepada laporan serangan OPT penting tanaman kopi di wilayah Provinsi Jawa Barat periode triwulan IV tahun 2017, sebanyak 5.122.28 Ha dari total luas area perkebunan 32.332.40 Ha terkena serangan dengan berbagai macam OPT diantaranya adalah Penggerek Buah (Hypothenemus hampeii), Karat Daun (Hemileia vastatrik), Busuk Buah (Cercospora coffeae), Penggerek Batang (Xyleborus compactus), Kutu Hijau (Coccus viridis), Parasit (Nematoda) [3]. Pengendalian terhadap serangan penyakit dan hama tanaman kopi perlu dilakukan untuk menekan perkembangan populasi hama agar tidak merugikan secara ekonomis dan dapat meningkatkan ketahanan tanaman kopi.

Diagnosis adalah langkah pertama yang harus dilakukan untuk menganalisis dan mengindentitikasi gejala serangan OPT yang terjadi pada tanaman kopi. Langkah ini dilakukan untuk mengetahui cara penanganan dan pengendalian yang tepat terhadap serangan tersebut. Setiap serangan OPT yang terjadi pada tanaman kopi memiliki gejala dan cara pengendalian yang berbeda satu sama lain [4]. Diagnosis yang tepat dan akurat tentunya akan berdampak terhadap cara pengendalian yang tepat pula. Untuk melakukan diagnosis dan pengendalian yang tepat, diperlukan pengetahuan dan kepakaran tertentu terhadap gejala serangan dan cara pengendalian serangan hama. Dalam hal ini pengetahuan dan kepakaran tersebut hanya dimiliki oleh sumber daya manusia yang berada di lingkungan Balai Proteksi Tanaman Perkebunan (BPTP) Provinsi Jawa Barat. Berbagai upaya telah dilakukan oleh pihak BPTP Provinsi Jawa Barat untuk mendukung penanganan serangan hama yang terjadi pada perkebunan kopi. Kegiatan ini meliputi sosialisasi dan edukasi mengenai pengenalan dan pengendalian OPT kopi serta meluncurkan teknologi terbaru kepada para petani untuk mengendalikan serangan hama. Salah satu teknologi yang di kembangkan dan di uji coba pada april 2017 adalah formulasi cair Metabolit Sekunder Agensia Pengendali Hayati (APH) pada serangan karat daun, pengerek buah dan kutu hijau [5]. Dari hasil uji coba yang dilakukan, dengan dosis yang tepat formulasi ini dapat mengendalikan serangan hama yang terjadi.

Luasnya areal perkebunan kopi di Jawa Barat serta keterbatasan sumber daya manusia yang memiliki kepakaran terhadap OPT kopi menjadi kendala tersendiri bagi pihak BPTP untuk melakukan sosialisasi dan edukasi. Hal ini berdampak terhadap lambatnya penanganan serangan OPT yang terjadi. Pada sisi yang lain, petani sulit melakukan penanganan dikarenakan keterbatasan pengetahuan yang dimiliki. Untuk mendapatkan pengetahuan OPT kopi, petani harus menunggu sosialisasi atau berinisiatif berkonsultasi langsung dengan pihak BPTP Provinsi Jawa Barat. Proses ini tentunya akan memakan biaya perjalanan yang besar serta membutuhkan waktu yang sangat lama karena letak geografis perkebunan kopi dengan instansi terkait dalam hal ini balai proteksi tanaman perkebunan provinsi jawa barat yang sangat jauh. Untuk mengatasi permasalahan tersebut, penulis bermaksud membuat aplikasi berbasis web untuk menjembatani dan mengakomodasi bentuk edukasi yang dapat dilakukan kapan saja dan dimana saja tidak terbatas oleh letak geografis dan waktu. Melalui aplikasi web ini, para petani dapat mengetahui informasi gejala, serangan serta cara pengendalian OPT kopi. Selain itu, petani dapat melakukan diagnosis secara mandiri dengan melakukan penelusuran pertanyaaan yang berkaitan dengan gejala serangan yang dialami untuk kemudian mendapatkan informasi penanganan serta pengendalian yang tepat.

Sistem berbasis pengetahuan, fakta dan teknik penalaran dalam memecahkan sebuah masalah oleh seorang pakar atau yang sering disebut sebagai sistem pakar [6] diaplikasikan dalam aplikasi web ini. Pengetahuan dan fakta mengenai gejala, serangan serta pengendalian OPT kopi yang dimiliki oleh pakar di balai proteksi tanaman perkebunan Provinsi Jawa Barat dituangkan dan diadopsi dalam aplikasi ini, sehingga ketika petani melakukan diagnosis terhadap gejala serangan melalui aplikasi ini setara dengan proses petani melakukan konsultasi secara langsung dengan pakar tanaman kopi. Diagnosis yang diadopsi pada aplikasi web ini menggunakan metode forward chaining dimana metode yang dilakukan adalah dengan cara menelusuri serta mencocokan fakta atau pernyataan secara maju sampai dengan menemukan kesimpulan [7] [8]. Dengan penerapan sistem pakar menggunakan forward chaining, aplikasi web ini dapat memberikan kesimpulan gejala serangan yang terjadi serta memberikan solusi pengendalian yang tepat bagi 
para petani. Pada penelitian ini, penelusuran gejala serangan secara lebih spesifik dengan menggunakan kalimat pertanyaaan bersifat terbatas yang dilengkapi bentuk visual, sehingga petani yang memberikan jawaban diarahkan untuk mendapatkan alternatif jawaban yang lebih spesifik.

\section{METODOLOGI PENELITIAN}

Untuk membangun aplikasi, penulis mengadopsi prinsip-prinsip Software Development Life Cycle $(S D L C)$ dimana proses pengembangan perangkat lunak menggunakan model-model dan metodologi yang digunakan orang berdasarkan best practice atau cara-cara pengembangan perangkat lunak yang sudah teruji dengan baik. Dari beberapa model yang terdapat pada SDLC, model Waterfall menjadi pilihan metodologi pengembangan perangkat lunak yang akan dibangun pada penelitian ini. Model ini dipilih untuk mempermudah pembangunan perangkat lunak secara terurut yang dimulai dari tahapan analisis, desain, pengodean, pengujian dan tahap pendukung [9]. Ilustrasi model waterfall dapat dilihat pada gambar 1.

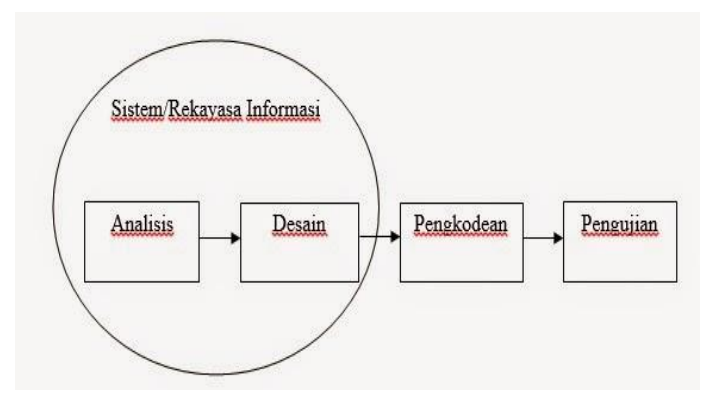

Gambar 1. Model Waterfall [9]

\subsection{Tahapan Analisis}

Seluruh kebutuhan aplikasi web sistem pakar diagnosis penyakit tanaman kopi harus bisa didapatkan dalam fase ini, termasuk didalamnya kegunaan aplikasi web yang diharapkan pengguna. Informasi ini dapat diperoleh melalui wawancara, survey, observasi maupun diskusi. Informasi tersebut dianalisis untuk mendapatkan dokumentasi kebutuhan pengguna untuk digunakan pada tahap selanjutnya. Pemodelan kebutuhan pada penelitian ini menggunakan Unified Modelling Language (UML).

\subsection{Tahapan Desain}

Tahap ini bertujuan untuk memberikan gambaran dan membantu dalam menspesifikasikan desain perangkat lunak sistem pakar diagnosis penyakit tanaman kopi secara keseluruhan. Tahapan ini mencakup pembuatan struktur data, arsitektur perangkat lunak, representasi antar muka dan prosedur pengodean.

\subsection{Tahapan Pengkodean}

Tahap ini bertujuan untuk menterjemahkan hasil desain yang telah dilakukan ke dalam program perangkat lunak. Pada tahapan ini penulis menggunakan Bahasa pemrograman PHP dan basis data menggunakan MySQL. Hasil dari tahapan ini harus sesuai dengan desain yang telah dibuat pada tahapan sebelumnya.

\subsection{Tahapan Pengujian}

Tahap ini bertujuan untuk melakukan pengujian terhadap perangkat lunak baik secara lojik maupun secara fungsional. Setiap hasil pengkodean akan diuji untuk memastikan tidak ada kesalahan serta memastikan bahwa keluaran yang dihasilkan oleh perangkat lunak telah sesuai dengan kebutuhan yang diinginkan.

\section{HASIL DAN PEMBAHASAN}

\subsection{Hasil dan Pembahasan Tahapan Analisis}

Analisis kebutuhan fungsional dilakukan dengan melakukan wawancara kepada pihak balai proteksi tanaman perkebunan Provinsi Jawa Barat untuk mengakomodasi kepakaran dan pengetahuan dari gejala dan pengendalian OPT Kopi serta kepada pihak petani untuk mengakomodasi kebutuhan penggunaan 
aplikasi yang diinginkan. Hasil dari wawancara ini dibuatkan dalam bentuk fungsional Use Case seperti tertera pada gambar 2

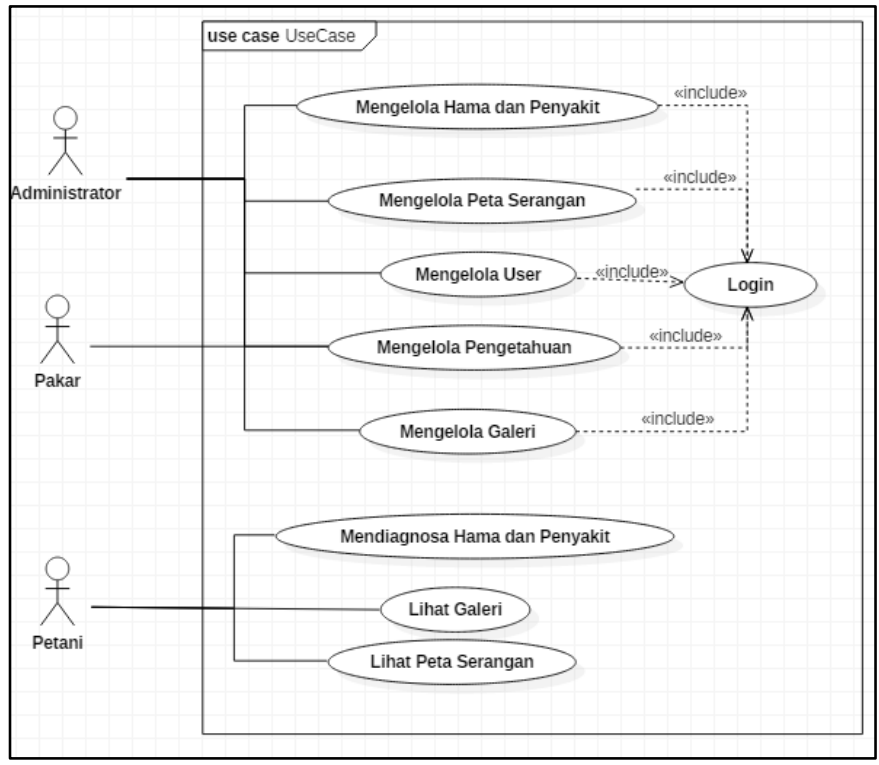

Gambar 2. Use Case Aplikasi Web

\subsection{Hasil dan Pembahasan Tahapan Desain}

Merujuk kepada metode forward chaining yang mempunyai cara kerja menelusuri serta mencocokan fakta atau pernyataan secara maju sampai dengan menemukan kesimpulan, maka dibuatkan rancangan antar muka untuk mengakomodasi proses ini berupa pertanyaan-pertanyaan yang dijawab oleh pengguna dengan jawaban ya atau tidak seperti yang tertera pada gambar 3 sampai dengan menghasilkan kesimpulan hasil diagnosis yang berisi mengenai gejala, ciri serangan dan cara pengendalian OPT seperti yang tertera pada gambar 4 .

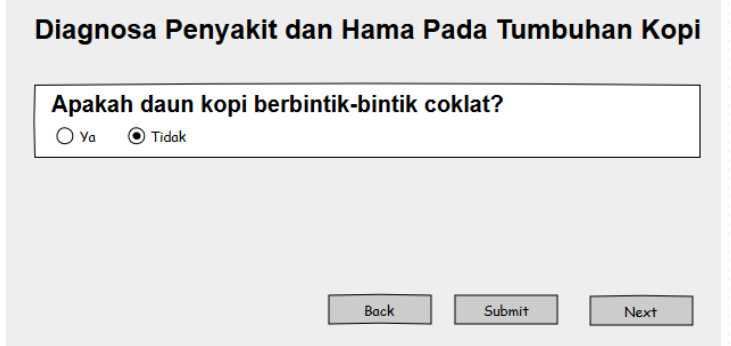

Gambar 3. Rancangan Antar Muka Diagnosis OPT Kopi 


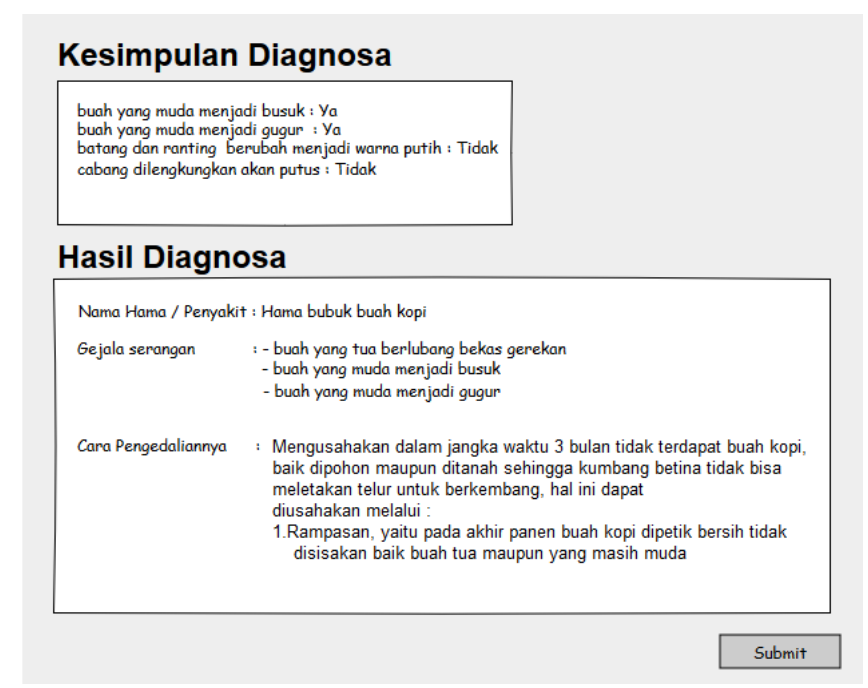

Gambar 4. Rancangan Antar Muka Diagnosis OPT Kopi

Untuk memudahkan desain pemetaan penelusuran pengetahuan OPT Kopi sesuai dengan metode forward chaining maka dibuatkan tabel pengetahuan seperti tertera pada tabel 1, untuk kemudian dibuatkan pohon keputusan seperti tertera pada gambar 5. Pengetahuan gejala yang di aplikasikan pada penelitian ini merujuk kepada buku Pengenalan dan Pengendalian Organisme Pengganggu Tumbuhan (OPT) Tanaman Kopi tahun 2017 yang dikeluarkan oleh Direktrorat Perlindungan Perkebunan Direktorat Jenderal Perkebunan Kementerian Pertanian [10]. Penggunaan buku ini berdasarkan masukan dan arahan dari hasil wawancara dengan Kepala Seksi Sarana Teknologi PHT Balai Proteksi Tanaman Perkebunan Dinas Perkebunan Provinsi Jawa Barat.

Tabel 1. Tabel pengetahuan gejala opt kopi

\begin{tabular}{|c|c|c|c|}
\hline No & Nama OPT & Kode & Gejala \\
\hline \multirow[t]{3}{*}{$\mathrm{K} 1$} & $\begin{array}{l}\text { Penggerek buah } \\
\text { Kopi/PBKo }\end{array}$ & G1 & $\begin{array}{l}\text { Serangan pada buah muda menyebabkan buah tidak berkembang, } \\
\text { lama kelamaan berwarna kuning kemerahan kemudian gugur. }\end{array}$ \\
\hline & & $\mathrm{G} 2$ & $\begin{array}{l}\text { Serangan pada buah tua menyebabkan biji kopi rusak. Jika dibelah, } \\
\text { terdapat larva, pupa dan imago PBKo. }\end{array}$ \\
\hline & & G3 & $\begin{array}{l}\text { Serangan pada buah tua, mengakibatkan biji berlubang sehingga } \\
\text { menurunkan mutu kopi. }\end{array}$ \\
\hline $\mathrm{K} 2$ & Kutu Putih & G4 & $\begin{array}{l}\text { Buah dan bunga kopi yang terserang kutu putih mengering dan gugur. } \\
\text { Serangan pada buah tua mengakibatkan buah mengerut dan masak } \\
\text { sebelum waktunya }\end{array}$ \\
\hline K3 & $\begin{array}{l}\text { Penggerek } \\
\text { batang(Zeuzera } \\
\text { Coffeae) }\end{array}$ & G5 & $\begin{array}{l}\text { Daun kopi terlihat menguning dan adanya liang gerekan pada batang } \\
\text { disertai dengan adanya kotoran yang berwarna merah kehitam- } \\
\text { hitaman yang keluar dari liang gerekan( lubang aktif) }\end{array}$ \\
\hline \multirow[t]{2}{*}{ K4 } & Karat daun kopi & G6 & $\begin{array}{l}\text { Bercak berwarna kuning muda pada permukaan bawah daun } \\
\text { kemudian berubah menjadi kuning tua dan terbentuk tepung }\end{array}$ \\
\hline & & G7 & $\begin{array}{l}\text { Daun yang terserang gugur sebelum waktunya. Serangan berat dapat } \\
\text { menyebabkan pohon menjadi gundul, cabang/ranting mati dan } \\
\text { akhirnya tanaman mati }\end{array}$ \\
\hline \multirow[t]{2}{*}{ K5 } & Busuk Buah & G8 & $\begin{array}{l}\text { Terdapat bercak berwarna hitam yang meluas hingga seluruh buah } \\
\text { berwarna hitam }\end{array}$ \\
\hline & & G9 & Terdapat spora berwarna putih yang merupakan spora jamur. \\
\hline \multirow[t]{3}{*}{ K6 } & Kutu Hijau & G10 & $\begin{array}{l}\text { Kutu hijau menyerang seluruh bagian tanaman yang masih berwarna } \\
\text { hijau dan muda. Serangan bisa terjadi pada buah, pucuk tanaman, } \\
\text { batang dan bunga. Serangan pada daun umumnya terjadi sepanjang } \\
\text { tulang daun. }\end{array}$ \\
\hline & & G11 & $\begin{array}{l}\text { Kutu hijau dan jenis kutu tanaman lainnya mengeluarkan senyawa } \\
\text { berupa madu sebagai ekskresinya. }\end{array}$ \\
\hline & & G12 & $\begin{array}{l}\text { Populasi kutu hijau telah terlalu besar, senyawa ekskresi tadi biasanya } \\
\text { sering menutupi bagian permukaan tanaman. }\end{array}$ \\
\hline
\end{tabular}




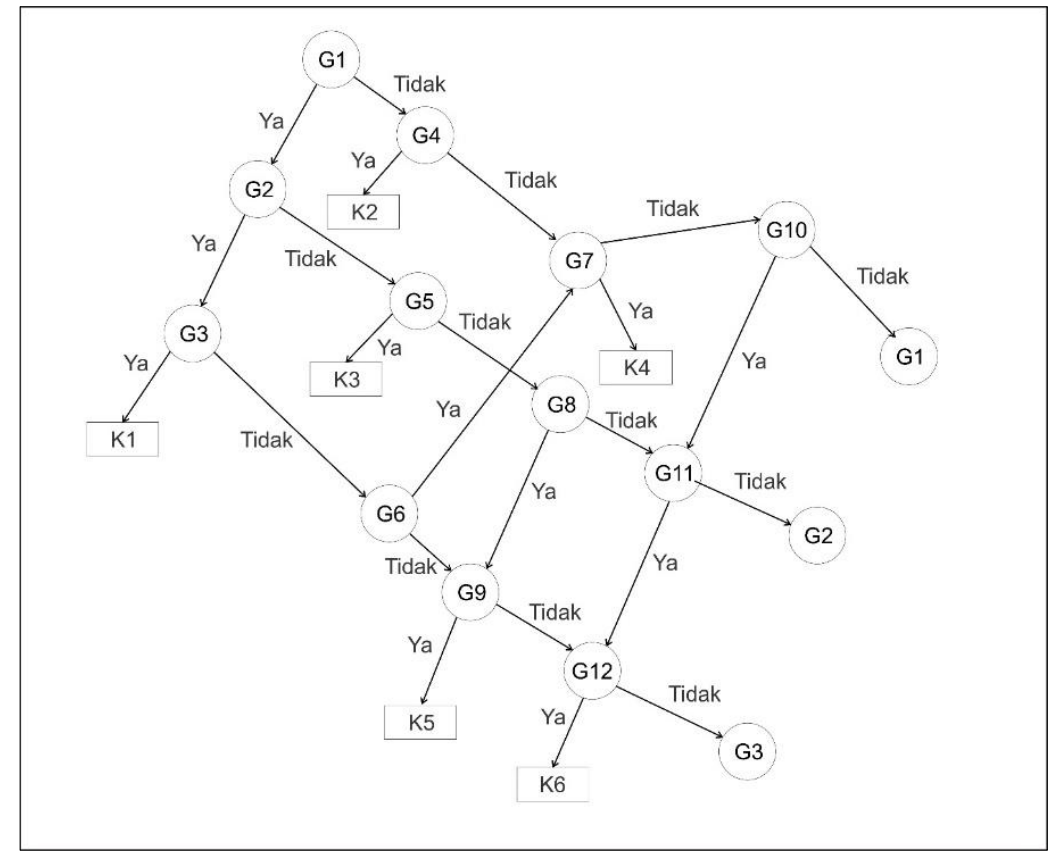

\section{Gambar 5. Pohon Keputusan Penelusuran Gejala Serangan OPT Kopi}

\subsection{Hasil dan Pembahasan Tahapan Pengkodean}

Hasil pengkodean dilakukan sesuai dengan hasil desain pohon keputusan yang dibuat. Sebagai contoh jika penelusuran pertanyaan G1 berisi jawaban ya, maka selanjutnya akan maju ke pertanyaan G2. Jika pertanyaan G2 berisi jawaban ya, maka selanjutnya akan maju ke pertanyaan G3. Jika pertanyaan G3 berisi jawaban ya maka akan keluar kesimpulan K1. Proses ini dapat dilihat secara berturut-turut pada gambar 6,7,8 dan 9 hasil pengkodean penelusuran pertanyaan.

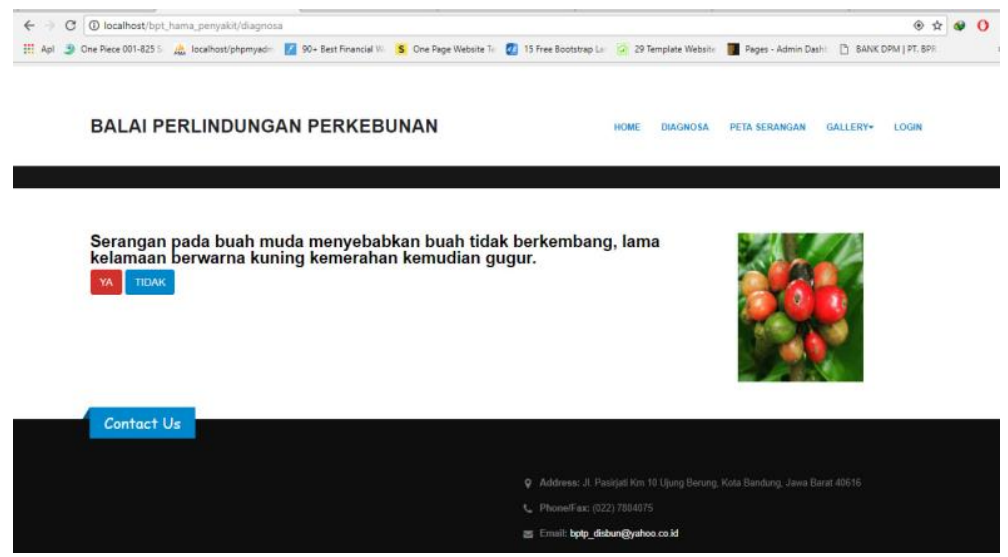

Gambar 6. Antar Muka Penelusuran Pertanyaan G1 


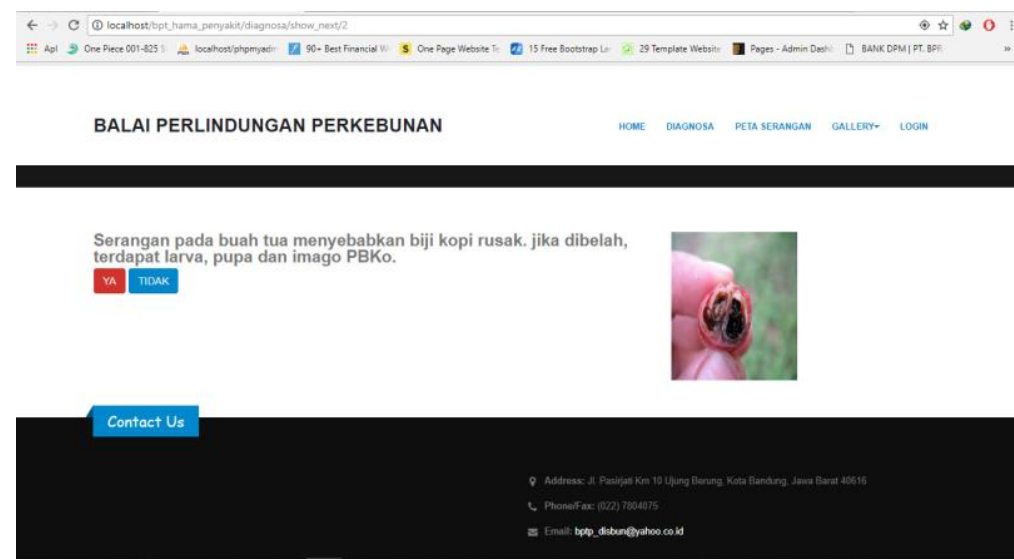

Gambar 7. Antar Muka Penelusuran Pertanyaan G2

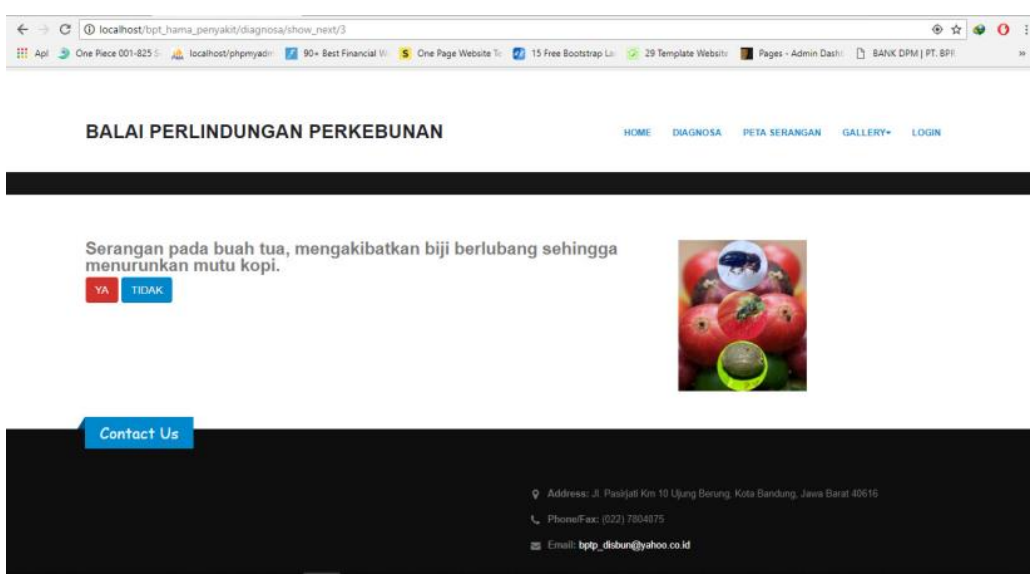

Gambar 8. Antar Muka Penelusuran Pertanyaan G3

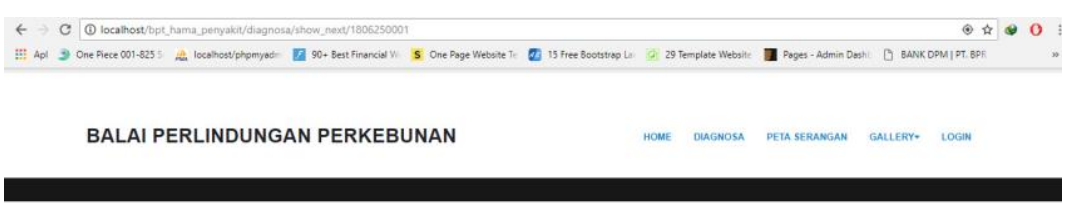

Hasil diagnosa menunjukan bahwa perkebunan anda terserang OPT Penggerek buah Kopi/PBKo

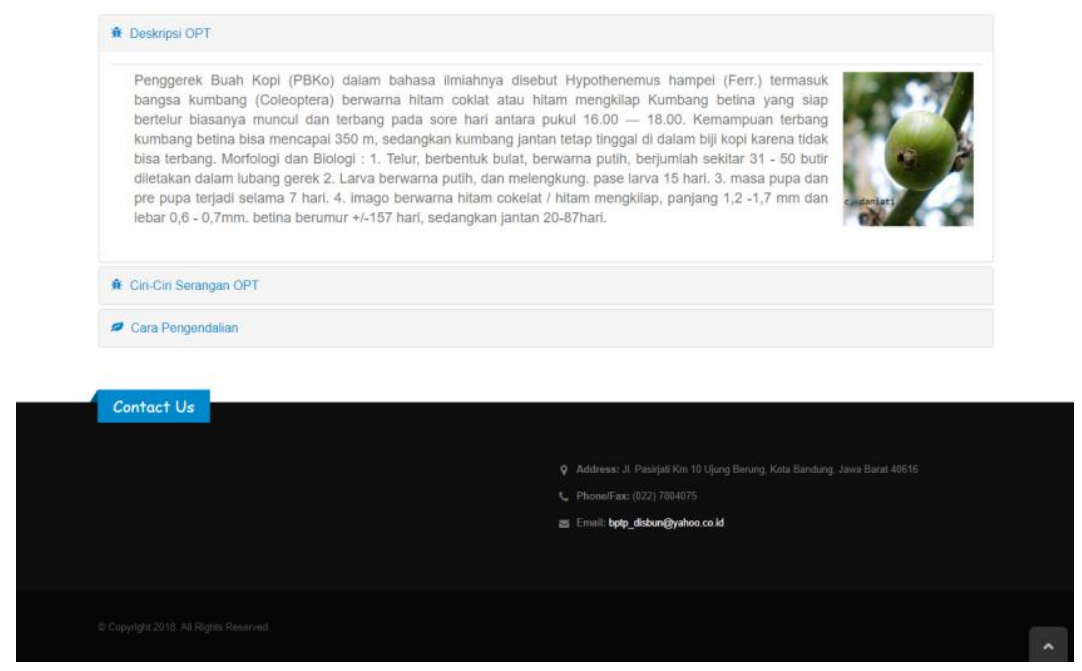

Gambar 9. Antar Muka Hasil Diagnosis K1 


\subsection{Hasil dan Pembahasan Tahapan Pengujian}

Pengujian dilakukan secara kualitatif terhadap aplikasi web sistem pakar yang dibangun. Pengujian dilakukan sebanyak dua tahapan. Pengujian tahap pertama seperti yang tertera pada tabel 2 dilakukan oleh perwakilan dari pihak balai proteksi tanaman perkebunan provinsi jawa barat yaitu petugas brigade proteksi tanaman. Hal ini ditujukan untuk mengklarifikasi dan memastikan basis pengetahuan/kepakaran mengenai gejala, serangan dan pengendalian OPT kopi sudah sesuai dan telah terakomodasi dengan baik di dalam perangkat lunak. Pengujian tahap kedua seperti yang tertera pada tabel 3 dilakukan oleh 25 responden perwakilan petani dalam hal ini diwakilkan oleh Gabungan Kelompok Tani Kelompok Swadaya Masyarakat (KSM) Preanger Spesiality Desa Mekarwangi Kabupaten Bandung Barat. Hal ini ditujukan untuk mengetahui seberapa baik kualitas informasi dan kemudahan penggunaan aplikasi dalam mencari informasi gejala, serangan, bentuk visual dan pengendalian OPT kopi.

Tabel 2. Hasil pengujian pihak bptp provinsi Jawa Barat

\begin{tabular}{|c|c|c|c|c|c|}
\hline No & Cara pengujian & $\begin{array}{c}\text { Hasil yang } \\
\text { diharapkan }\end{array}$ & $\begin{array}{l}\text { Hasil yang } \\
\text { didapatkan }\end{array}$ & Valid & $\begin{array}{l}\text { Tidak } \\
\text { Valid } \\
\end{array}$ \\
\hline 1 & $\begin{array}{l}\text { Menampilkan pengetahuan } \\
\text { dan menyamakan } \\
\text { pengetahuan pakar dengan } \\
\text { sistem }\end{array}$ & $\begin{array}{l}\text { Pengetahuan } \\
\text { sama dan } \\
\text { benar }\end{array}$ & $\begin{array}{l}\text { Sama dan } \\
\text { benar }\end{array}$ & V & \\
\hline 2 & $\begin{array}{l}\text { Menampilkan data hama } \\
\text { penyakit dan penjelasannya }\end{array}$ & $\begin{array}{l}\text { Data tanaman } \\
\text { tersedia dan } \\
\text { sesuai dengan } \\
\text { pengetahuan } \\
\text { pakar }\end{array}$ & $\begin{array}{l}\text { Data sesuai } \\
\text { dengan } \\
\text { pengetahuan } \\
\text { pakar }\end{array}$ & V & \\
\hline 3 & $\begin{array}{l}\text { Memiliki data gejala } \\
\text { serangan dan penjelasannya }\end{array}$ & $\begin{array}{l}\text { Data ciri ciri } \\
\text { tersedia dan } \\
\text { sesuai dengan } \\
\text { pengetahuan } \\
\text { pakar }\end{array}$ & $\begin{array}{l}\text { Data sesuai } \\
\text { dengan } \\
\text { pengetahuan } \\
\text { pakar }\end{array}$ & V & \\
\hline 4 & $\begin{array}{l}\text { Menampilkan pernyataan } \\
\text { untuk mendiagnosis secara } \\
\text { detail }\end{array}$ & $\begin{array}{l}\text { Menampilkan } \\
\text { pernyataan } \\
\text { pada tampilan } \\
\text { browser }\end{array}$ & $\begin{array}{l}\text { Pernyataan } \\
\text { tampil pada } \\
\text { browser } \\
\text { secara detail } \\
\text { dengan } \\
\text { penjelasan } \\
\text { nya }\end{array}$ & $v$ & \\
\hline 5 & $\begin{array}{l}\text { Menampilkan hasil dari } \\
\text { diagnosis yang dilakukan }\end{array}$ & $\begin{array}{l}\text { Menampilkan } \\
\text { cara } \\
\text { pengendalian } \\
\text { dan } \\
\text { penjelasannya }\end{array}$ & $\begin{array}{l}\text { Data Hama } \\
\text { atau penyakit } \\
\text { muncul dan } \\
\text { penjelasannya } \\
\text { muncul }\end{array}$ & V & \\
\hline 6 & $\begin{array}{l}\text { Sistem menampilkan profil } \\
\text { diagnosis }\end{array}$ & $\begin{array}{l}\text { Menampilkan } \\
\text { profile } \\
\text { mendiagnosa }\end{array}$ & $\begin{array}{l}\text { Data ciri-ciri } \\
\text { gejala yang } \\
\text { dipilih user }\end{array}$ & $v$ & \\
\hline
\end{tabular}

Tabel 3. Hasil pengujian pihak gapoktan ksm preanger spesialty desa Mekarwangi

\begin{tabular}{clcccccc}
\hline No & Cara pengujian & $\begin{array}{c}\text { Hasil yang } \\
\text { diharapkan }\end{array}$ & Setuju & $\begin{array}{c}\text { \% } \\
\text { Setuju }\end{array}$ & $\begin{array}{c}\text { Tidak } \\
\text { Setuju }\end{array}$ & $\begin{array}{c}\text { \% Tidak } \\
\text { Setuju }\end{array}$ & Total \\
\hline 1 & $\begin{array}{l}\text { Apakah program } \\
\text { memberikan } \\
\text { kemudahan untuk } \\
\text { penguna }\end{array}$ & $\begin{array}{l}\text { Memberi } \\
\text { kemudahan bagi } \\
\text { penguna }\end{array}$ & 22 & $88 \%$ & 3 & $12 \%$ & 25 \\
2 & $\begin{array}{l}\text { Tampilan program } \\
\text { nyaman untuk } \\
\text { dilihat }\end{array}$ & $\begin{array}{l}\text { Tampilan } \\
\text { program tidak } \\
\text { membuat mata } \\
\text { menjadi pusing } \\
\text { Mempermudah } \\
\text { dalam pencarian } \\
\text { data yang } \\
\text { diperlukan }\end{array}$ & 24 & $88 \%$ & 3 & $12 \%$ & 25 \\
\hline $\begin{array}{l}\text { Infomasi yang } \\
\text { diberikan sangat } \\
\text { jelas }\end{array}$ & & & & & & & \\
\hline
\end{tabular}




\begin{tabular}{|c|c|c|c|c|c|c|c|}
\hline No & Cara pengujian & $\begin{array}{c}\text { Hasil yang } \\
\text { diharapkan }\end{array}$ & Setuju & $\begin{array}{c}\% \\
\text { Setuju }\end{array}$ & $\begin{array}{l}\text { Tidak } \\
\text { Setuju }\end{array}$ & $\begin{array}{c}\text { \% Tidak } \\
\text { Setuju }\end{array}$ & Total \\
\hline 5 & $\begin{array}{l}\text { Informasi dalam } \\
\text { bentuk Naratif } \\
\text { (Deskripsi, Gejala, } \\
\text { Pengendalian) } \\
\text { OPT Kopi sesuai } \\
\text { dengan kejadian } \\
\text { dilapangan }\end{array}$ & $\begin{array}{l}\text { Penjelasan yang } \\
\text { di tampilkan } \\
\text { program mudah } \\
\text { untuk di pahami }\end{array}$ & 21 & $84 \%$ & 4 & $16 \%$ & 25 \\
\hline 6 & $\begin{array}{l}\text { Informasi dalam } \\
\text { bentuk Visual } \\
\text { (Deskripsi, Gejala, } \\
\text { Pengendalian) } \\
\text { OPT Kopi sesuai } \\
\text { dengan kejadian } \\
\text { dilapangan }\end{array}$ & $\begin{array}{l}\text { Bentuk visual } \\
\text { yang ditampilkan } \\
\text { program Sesuai } \\
\text { dengan yang } \\
\text { ditemukan oleh } \\
\text { petani di } \\
\text { perkebunan kopi }\end{array}$ & 24 & $96 \%$ & 1 & $4 \%$ & 25 \\
\hline 7 & $\begin{array}{l}\text { Aplikasi } \\
\text { memberikan } \\
\text { edukasi tambahan } \\
\text { berkaitan dengan } \\
\text { OPT Kopi }\end{array}$ & $\begin{array}{l}\text { Memberikan } \\
\text { wawasan } \\
\text { tambahan bagi } \\
\text { para petani }\end{array}$ & 20 & $80 \%$ & 5 & $20 \%$ & 25 \\
\hline \multirow[t]{2}{*}{8} & $\begin{array}{l}\text { Aplikasi } \\
\text { memberikan } \\
\text { alternatif solusi } \\
\text { terhadap serangan } \\
\text { OPT di lapangan }\end{array}$ & $\begin{array}{l}\text { Memberikan } \\
\text { alternatif solusi } \\
\text { pengendalian }\end{array}$ & 19 & $76 \%$ & 6 & $24 \%$ & 25 \\
\hline & & & 152 & $87 \%$ & 23 & $13 \%$ & 175 \\
\hline
\end{tabular}

Beberapa saran dan masukan untuk hal yang belum termasuk didalam pengujian yang didapatkan dari pihak BPTP dan Gapoktan diantaranya adalah penambahan informasi dampak kerugian ekonomi yang ditimbulkan oleh serangan OPT serta penambahan informasi ketersediaan dan kemudahan para petani untuk mendapatkan obat pengendali serangan OPT.

\section{KESIMPULAN}

Dari hasil pengujian yang dilakukan terhadap aplikasi web yang dibangun, implementasi metode forward chaining dapat membantu para petani kopi dilapangan untuk bisa melakukan diagnosis secara mandiri tanpa harus berkonsultasi langsung dengan pakar tanaman kopi. Selain itu, sistem pakar yang dibangun dapat diandalkan sebagai media edukasi budidaya serta pengendalian serangan OPT kopi. Pada penelitian berikutnya akan dilakukan pengujian validasi metode forward chaining dalam mendiagnosis OPT kopi dengan menggunakan beberapa variasi pohon penelusuran keputusan dan gejala serangan OPT untuk mendapatkan nilai akurasi penelusuran yang dibangun.

\section{UCAPAN TERIMA KASIH}

Terima kasih kepada pihak Balai Proteksi Tanaman Perkebunan Dinas Perkebunan Provinsi Jawa Barat dan Gapoktan KSM Preanger Spesialty Desa Mekarwangi yang telah memfasilitasi data, wawancara, observasi serta pengujian penelitian ini. Terima kasih juga penulis ucapkan kepada pihak Direktorat Riset dan Pengabdian Masyarakat (DRPM) Kemenristek DIKTI yang telah memfasilitasi penulis untuk melaksanakan Penelitian Dosen Pemula.

\section{DAFTAR PUSTAKA}

[1] D. P. P. J. Barat, 3 Oktober 2016. [Online]. Available: http://disbun.jabarprov.go.id/bptp/id/postdetail/110/Tanaman-Kopi-Jawa-Barat-Berperan-Strategis-Dalam-Rangka-Hari-Kopi-Internasional2016. [Accessed 30 November 2018].

[2] B. P. d. P. Pertanian, Teknologi Pengendalian Hama dan Penyakit Tanaman Kopi, Jakarta: Indonesian Agency For Agricultural Research and Development (IAARD) Press, 2015.

[3] B. P. T. P. P. J. Barat, "Laporan Serangan OPT Penting Tanaman Kopi di Wilayah Provinsi Jawa Barat Periode Triwulan IV Tahun 2017," Dinas Perkebunan Provinsi Jawa Barat, Bandung, 2017. 
[4] F. Diyasti, Y. Astuti, C. Subarjah and N. Isnaini, Pengenalan dan Pengendalian Organisme Pengganggu Tumbuhan (OPT), Jakarta: Direktorat Perlindungan Perkebunan Direktorat Jenderal Perkebunan Kementerian Pertanian, 2017.

[5] A. A. Putri, "BPTP Jawa Barat," 31 Agustus 2017. [Online]. Available: http://disbun.jabarprov.go.id/bptp/en/post-detail/204/Uji-Coba-Teknologi-Terbaru-untukPengendalian-OPT-pada-Tanaman-Kopi-di-Kabupaten-Bandung. [Accessed 4 Desember 2018].

[6] M. Silmi, E. A. Sarwoko and K. , "Sistem Pakar Berbasis Web dan Mobile Web Untuk Mendiagnosis Penyakit Darah Pada Manusia Dengan Menggunakan Metode Inferensi Forward Chaining," Jurnal Masyarakat Informatika, vol. 4, no. 7, pp. 31-38, 2013.

[7] G. A. K. Tutik, R. Delima and U. Proboyekti, "Penerapan Forward Chaining Pada Program Diagnosa Anak Penderita Autisme," Jurnal Informatika, vol. 5, no. 2, pp. 1-15, 2018.

[8] S. Rakasiwi and T. S. Albastomi, "Sistem Pakar Diagnosa Penyakit Udang Vannamei Menggunakan Metode Forward Chaining Berbasis Web," Simetris : Jurnal Teknik Mesin, Elektro dan Ilmu Komputer, vol. 8, no. 2, p. 647, 2017.

[9] R. A. S. and M. Shalahuddin, Rekayasa Perangkat Lunak Terstruktur dan Berorientasi Objek, Bandung: INFORMATIKA, 2015.

[10] F. Diyasti, Y. Astuti, C. Subarjah and N. Isnaini, Pengenalan dan Pengendalian Organisme Pengganggu Tumbuhan (OPT) Tanaman Kopi, Jakarta: Direktorat Perlindungan Perkebunan Direktorat Jenderal Perkebunan Kementerian Pertanian, 2017. 